Article

\title{
Novel DYRK1A Inhibitor Rescues Learning and Memory Deficits in a Mouse Model of Down Syndrome
}

\author{
Wenche Stensen ${ }^{1,2}$, Ulli Rothweiler ${ }^{1,2}$, Richard Alan Engh $\left.{ }^{1}{ }^{(}\right)$, Melissa R. Stasko ${ }^{3}$, Ilya Bederman ${ }^{3}(\mathbb{D}$, \\ Alberto C. S. Costa ${ }^{3}$, , Anders Fugelli ${ }^{2}$ and John S. Mjøen Svendsen ${ }^{1,2, *}$ (D) \\ 1 Department of Chemistry, UiT, The Arctic University of Norway, 9037 Tromsø, Norway; \\ wenche.stensen@uit.no (W.S.); ulli.rothweiler@uit.no (U.R.); richard.engh@uit.no (R.A.E.) \\ 2 Pharmasum Therapeutics AS, Gaustadalleen 21, 0349 Oslo, Norway; afugelli@pharmasum.com \\ 3 Departments of Pediatrics, Psychiatry, Macromolecular Science and Engineering, Case Western Reserve \\ University, 11100 Euclid Avenue, Cleveland, OH 44106, USA; mxs1081@case.edu (M.R.S.); \\ irb2@case.edu (I.B.); alberto.costa@case.edu (A.C.S.C.) \\ * Correspondence: john-sigurd.svendsen@uit.no
}

Citation: Stensen, W.; Rothweiler, U.; Engh, R.A.; Stasko, M.R.; Bederman, I.; Costa, A.C.S.; Fugelli, A.; Svendsen, J.S.M. Novel DYRK1A Inhibitor Rescues Learning and Memory Deficits in a Mouse Model of Down Syndrome. Pharmaceuticals 2021, 14, 1170. https://doi.org/ $10.3390 /$ ph14111170

\section{Academic Editors: Carlos}

Alberto Manssour Fraga and

Thierry Besson

Received: 8 October 2021

Accepted: 13 November 2021

Published: 17 November 2021

Publisher's Note: MDPI stays neutral with regard to jurisdictional claims in published maps and institutional affiliations.

Copyright: (c) 2021 by the authors. Licensee MDPI, Basel, Switzerland. This article is an open access article distributed under the terms and conditions of the Creative Commons Attribution (CC BY) license (https:// creativecommons.org/licenses/by/ $4.0 /)$.

\begin{abstract}
Down syndrome (DS) is a complex genetic disorder associated with substantial physical, cognitive, and behavioral challenges. Due to better treatment options for the physical co-morbidities of DS, the life expectancy of individuals with DS is beginning to approach that of the general population. However, the cognitive deficits seen in individuals with DS still cannot be addressed pharmacologically. In young individuals with DS, the level of intellectual disability varies from mild to severe, but cognitive ability generally decreases with increasing age, and all individuals with DS have early onset Alzheimer's disease (AD) pathology by the age of 40 . The present study introduces a novel inhibitor for the protein kinase DYRK1A, a key controlling kinase whose encoding gene is located on chromosome 21. The novel inhibitor is well characterized for use in mouse models and thus represents a valuable tool compound for further DYRK1A research.
\end{abstract}

Keywords: protein kinase inhibitor; DYRK1A; down syndrome; neurodegeneration; learning and memory deficits; mouse models

\section{Introduction}

Down syndrome (DS), first described by J. L. Down in 1866 [1], is a complex syndrome characterized by intellectual disability, distinctive facial features, low muscle tone (hypotonia), cardiac malformations, and leukemia in early infancy. In adulthood, DS is further complicated by additional health issues, such as early-onset Alzheimer's disease [2]. Lejeune, Turpin, and Gautier established in 1959 the genetic basis for DS [3] as the presence of an extra copy of chromosome 21 (HSA21), which was the first time a genetic basis for an intellectual disability was identified. Although it is likely that the multifaceted phenotypic patterns of DS are the result of the action of several genes acting in complex molecular networks, this idea does not preclude that modification of specific targets in these pathways may deliver rescuing of some of the clinical manifestations of DS.

The DYRK1A gene is the human, high-sequence-similarity orthologue of the Drosophila minibrain gene [4]. Null mutations of the minibrain gene affects postembryonic neurogenesis leading to reduction of brain size. The DYRK1A gene is highly conserved in vertebrates [5] and encodes a dual-specificity tyrosine phosphorylation-regulated kinase, DYRK1A. This enzyme appears to play a role during brain development by regulating neurogenesis and neuronal differentiation in mice [6]. DYRK1A is highly expressed in the brain [6,7] where it plays an important role in the adult central nervous system manifested by the diverse learning and memory deficits observed in DYRK1A transgenic mice [8]. Individuals with DS are trisomic for the DYRK1A gene, and brain expression levels of DYRK1A are increased approximately 1.5-fold in areas such as the frontal, temporal, and occipital cortices, and 
the cerebellum, indicating that this protein is overexpressed in a gene dosage-dependent manner $[9,10]$. The DYRK1A protein kinase may hence be regarded as an archetypical dosage sensitive gene product, where its underexpression leads to Autosomal Dominant Mental Retardation 7 (MRD7) [11] and its overexpression contributes to the cognitive dysfunction in persons with DS. Mice overexpressing DYRK1A show severe impairment in spatial learning and memory indicating alterations in both hippocampal and prefrontal cortical function [12], effects similar to those found in murine models of DS. DYRK1A also induces tau phosphorylation inhibiting the biological activity of tau, primes tauprotein for further phosphorylation by glycogen synthetase- $3 \beta$ (GSK-3 $\beta$ ) and promotes tau self-aggregation into neurofibrillary tangles (NFTs) [13]. The potential roles of DYRK1A on cognitive deficits in individuals with DS has recently been reviewed [14] suggesting that DYRK1A plays a key role in controlling cellular growth, neurogenesis and neuronal maturation. All the above observations implicate DYRK1A as a likely candidate for causing cognitive impairment in persons with DS.

In vivo models for DS are commonly murine based, although both Drosophila [4] and zebrafish [15] models are known. Mice have conserved synteny between chromosome 16 (MMU16) and the human chromosome 21 (HSA21) [16]. This shared synteny is the basis for mouse models of DS, such as the well-studied Ts65Dn [17] and the Ts1Cje [18] mice. The Ts65Dn has $\approx 104$ genes that are orthologous with HSA21, while Ts1Cje has a shorter set of overlapping orthologous genes $(\approx 84$ genes), but both mouse models show learning deficits as assessed by different behavioral tests.

To further advance research on the role of DYRK1A in dementia and cognition in DS, there is a clear need to have access to tool compounds that are highly active and highly selective against DYRK1A, while simultaneously being compatible with the requirements of animal models. In this work we present the design and preparation of PST-001, a potent and very selective inhibitor of DYRK1A, that is non-toxic, orally available, with good pharmacokinetic properties including penetration of the blood-brain barrier enabling advanced in vivo studies in mice. In the present work we outline the design and development of PST001 and verify its suitability in mouse models. Furthermore, by using the DYRK1A PST-001 inhibitor in Ts65Dn mice, learning and memory deficits in a contextual discrimination task seen in these animals can be rescued.

\section{Results}

The field of DYRK1A-active inhibitors has recently been extensively reviewed $[19,20]$. The first inhibitors described were harmine [21,22] and epigallocatechin gallate [23,24], but these have intrinsic problems, with the presence of PAINS motifs and potent MAO inhibition, respectively. Hence intense research for discovering new and more applicable inhibitors has been undertaken. The benzothiazole scaffold is among the more promising frameworks for DYRK1A inhibition, pioneered by the compounds INDY [25], luciferin [26], a library of fragment sized 2-acetamidobenzothiazole derivatives [27], and a series of thiazoloquinazolines [28-30]. The benzothiazole moiety appears to represent a privileged scaffold for DYRK-inhibition due to an unusual $\pi$-interaction between the benzothiazole sulfur atom in the inhibitor and the aromatic ring of the phenylalanine gatekeeper residue in the active site of the protein kinase [27]. A number of X-ray structures that accompanied the study of the 2-acetamidobenzothiazole fragments revealed multiple binding modes, but the common theme is that the substituent in the benzothiazole benzene ring interacts with Leu241 in the hinge region though hydrogen bonding, whereas the acetamido carbonyl group interacts with a salt bridge between Lys188 and Asp307. The latter interaction, however, is regarded as weak, as the molecules are too short to fully span the distance between the hinge and the salt bridge. Luciferin is another effective benzothiazole-containing inhibitor of DYRK1A, with a binding mode (determined on CDK2) resembling that of the 2-acetamidobenzothiazole fragments. In luciferin, the distance between the phenolic hydroxyl group and the carboxylate in the tricyclic molecule better meets the distance between the hinge and the salt bridge than for the benzothiazole fragments. With a phenolic hydroxyl group at the hinge and second arene group, its carboxylate moiety can interact 
more closely with the salt bridge. The dihydrothiazole ring in luciferin is regarded as insufficiently stable for use as an enzyme inhibitor, hence we replaced it with a chemically stable and similarly sized pyridine ring. A finding from the 2-acetamidobenzothiazole study was the position of the phenolic hydroxyl group in the benzothiazole, where the 5-position yielded more effective inhibitors than the 6-hydroxy analogs of luciferin. Using these structural clues, a molecule PST-001 was designed using the privileged benzothiazole scaffold (Figure 1), but with improved capacity to interact with the hinge and the salt bridge. The carboxylic acid moiety of luciferin was also replaced by an acetamido moiety, providing a molecule with calculated properties [31] compatible with oral availability $(\mathrm{MW}=299.353,5 \mathrm{H}$-bond acceptors, $1 \mathrm{H}$-bond donor, and clogP of 2.1246) [32].<smiles>COc1ccc2sc(NC(C)=O)nc2c1</smiles>

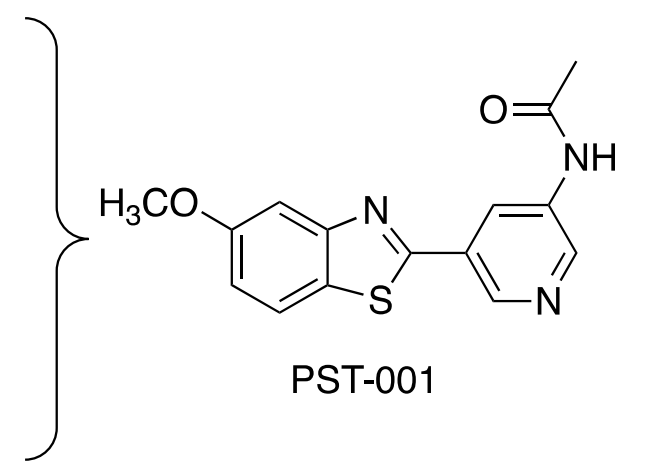

Figure 1. The design of PST-001.

PST-001 was prepared from 2-aminobenzothiazole through a direct palladium catalyzed coupling reaction with a bromopyridine forming 5-(5-methoxybenzo[d]thiazol-2yl)pyridin-3-amine before the acetamido moiety was introduced as shown in the Figure 2 below. The preparation of PST-001 is described in detail in the Supplementary Information (experimental procedures and Figures S1-S6).<smiles>COc1ccc2sc[nH+]c2c1</smiles>

Figure 2. Preparation of PST-001. Reagents and conditions. a: $\mathrm{Cs}_{2} \mathrm{CO}_{3}, \mathrm{Cu}(\mathrm{I}) \mathrm{Br}, \mathrm{Pd}(\mathrm{OAc})_{2}, \mathrm{P}(t-\mathrm{Bu})_{3}, \mathrm{DMF}, 150{ }^{\circ} \mathrm{C}, \mathrm{b}: \mathrm{Ac} \mathrm{O}_{2}$, pyridine, $\mathrm{CH}_{2} \mathrm{Cl}_{2}$, rt.

An X-ray crystallographic investigation of the complex between PST-001 and DYRK1A (Supplementary Information, Table S1) revealed that the PST-001 molecule fulfilled its design goals (Figure 3). PST-001 is a type 1 protein kinase inhibitor, which binds to the ATP site of the active form of the enzyme. The methoxy oxygen atom in the inhibitor forms a hydrogen bond to the backbone NH of Leu241 in the hinge, whereas the acetamide NH on the pyridine ring forms a hydrogen bond to Asp307 and the pyridine nitrogen atom make a hydrogen bond to Lys188. The unusual $\pi$-interaction between the benzothiazole sulfur atom and the gatekeeper Phe238 is also evident as is an additional sulfur- $\pi$ interaction between Met240 and the benzothiazole benzene ring.

The numerous binding interactions between PST-001 and DYRK1A translates to an effective inhibition of the DYRK1A enzyme with an $\mathrm{IC}_{50}$ value of $40 \mathrm{nM}$. 


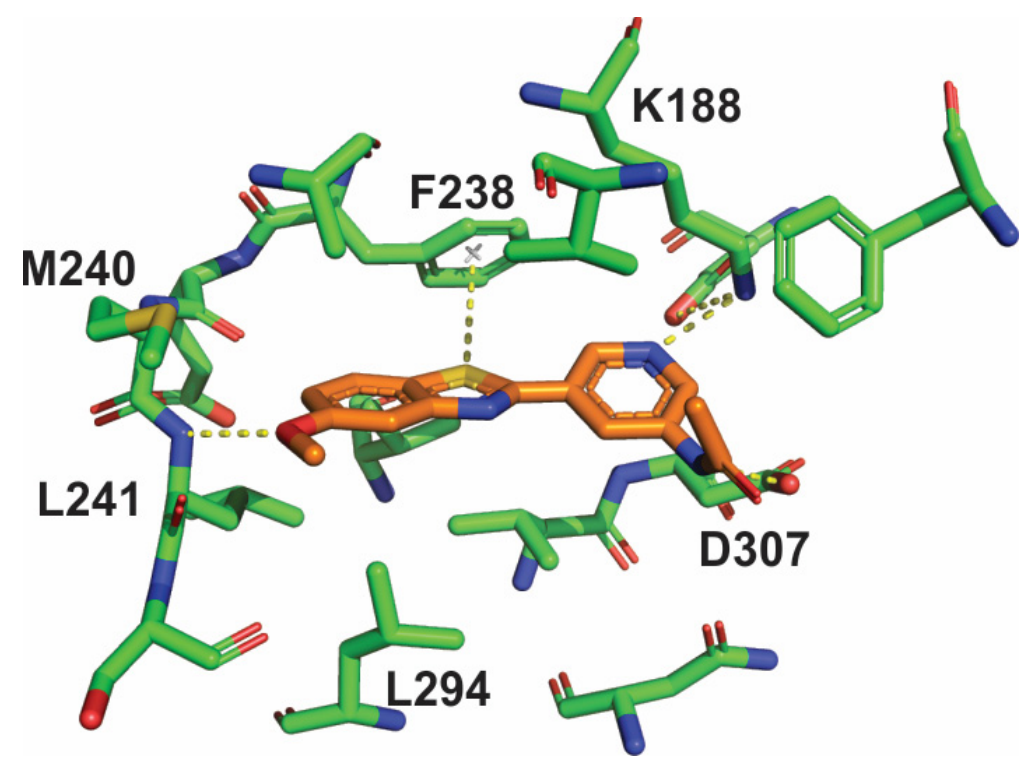

Figure 3. The binding mode, and main interactions of inhibitor PST-001 in the active site of the protein kinase DYRK1A as determined by X-ray crystallography.

Selectivity within the protein kinase family was considered equally important to target binding for the purpose of developing a new DYRK molecular tool. PST-001 was designed on a DYRK privileged scaffold [27] and revealed an unusually high GINI-index [33] of 0.936 when tested at $1 \mu \mathrm{M}$ ( 25 times the on-target $\mathrm{IC}_{50}$ value) on a 139-protein kinase panel (ATP concentrations were at or below the calculated $\mathrm{K}_{\mathrm{m}}$ for ATP for each particular kinase). To put the selectivity of PST-001 in context, harmine has a GINI-index of 0.506, while pan-kinome inhibitor staurosporine has a GINI-index of 0.093 (with $10 \mathrm{uM}$ ATP). Selected entries from the protein kinase profiling are shown in Table 1 (the full kinase profile tested at 1 and $100 \mu \mathrm{M}$ is given in Supplementary Information Table S2), showing that the main off-targets were the other members of the DYRK-family and CLK2. (Aurora A seemed to be moderately activated.) Most important is the lack of inhibitory activity against GSK3 $\beta$, a multifunctional protein kinase involved in phosphorylation of protein tau.

Table 1. Percent remaining inhibitory activity at high and low PST-001 concentration on a panel of protein kinases. The full profile data set is compiled in the Supplementary Information (Table S2).

\begin{tabular}{ccc}
\hline Kinase & \multicolumn{3}{c}{ \% Remaining Activity } \\
\hline DYRK1A & $100 \mu \mathrm{M}$ & $1 \mu \mathrm{M}$ \\
DYRK2 & 3 & 8 \\
DYRK3 & 4 & 21 \\
Aurora A & 5 & 20 \\
Aurora B & 136 & 133 \\
GSK3 $\beta$ & 24 & 106 \\
ERK8 & 100 & 107 \\
CLK2 & 28 & 89 \\
& 5 & 22 \\
\hline
\end{tabular}

The DYRK1A protein kinase is an intracellular and intranuclear enzyme, hence any effective inhibitor of DYRK1A must pass through both the cellular and the nuclear membranes. DYRK1A is involved in the NFAT/calcineurin signaling system [34], phosphorylating intranuclear NFATc. Upon phosphorylation, NFATc is trafficked out of the nucleus into the cytosol. The phosphorylated-NFATc in the cytosol may be dephosphorylated by $\mathrm{Ca}^{2+}$-activated calcineurin resulting in transport of the NFATc back into the nucleus. Inside the nucleus, NFATc forms a transcription complex with NFATn initiating the transcription of target genes. The involvement of nuclear DYRK1A in the NFAT/calcineurin 
system is utilized in a NFAT-Luciferin HEK293 cell assay. In this assay, the HEK293 cells are transfected with NFAT and DYRK1A plasmids such that the NFATc-phosphorylation via DYRK1A predominates over dephosphorylation of extranuclear phosphor-NFATc by calcineurin activated by $\mathrm{Ca}^{2+}$. In this situation, the NFAT-transcription complex will not be formed, and the luciferase gene will not be transcribed. If, however, DYRK1A is inhibited, reducing phosphorylation of NFATc, the NFAT-transcription complex will form, and the reporter luciferase will be produced [35]. The assay thus shows increasing luciferase activity provided the inhibitors are able to enter the cell nucleus and inhibit the elevated amounts of DYRK1A effectively. Figure 4 shows dose dependent luciferase activity as a function of PST-001 concentration, showing that PST-001 can enter the nucleus of the HEK293 cells and inhibit DYRK1A enzymatic activity when present at $\mu \mathrm{M}$ levels in the cell media. The exact IC50 value could not be determined as upper limit of luciferase activity could not be reached due to the limited solubility of PST-001 in the assay system.

3

2.5

1.5

.

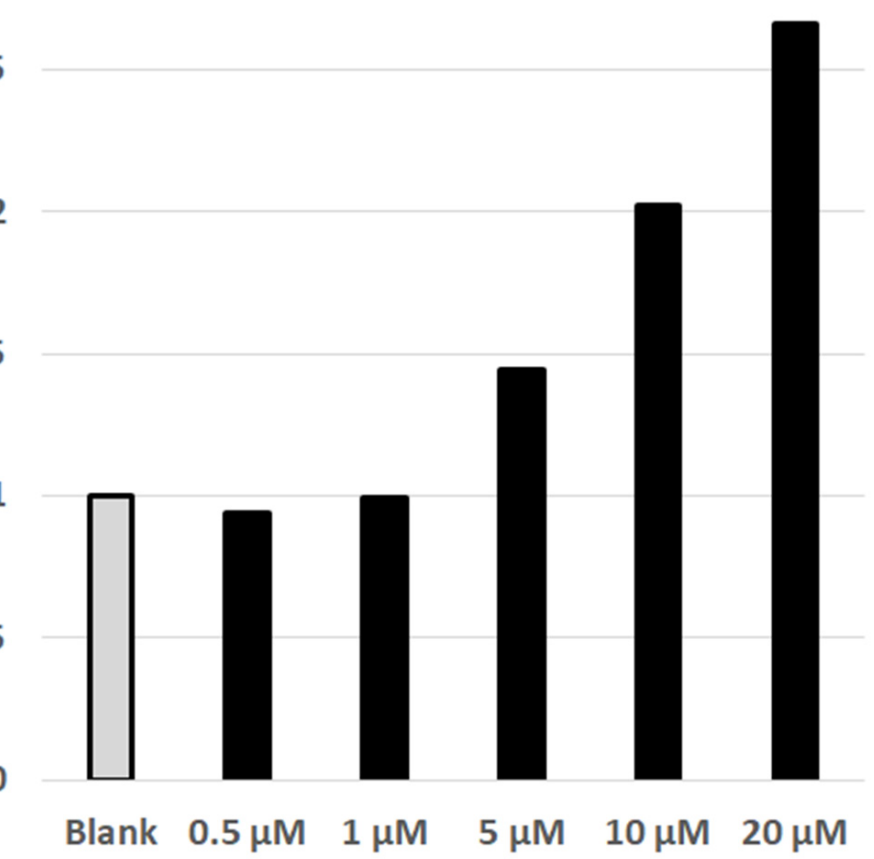

Figure 4. NFAT Luc reporter assay. The plot is normalized to the basal activity of the luciferase. Numbers indicate the fold of increase in luciferase activity upon inhibition of DYRK1A by PST-001.

The demonstration that PST-001 is able to modify the activity of intranuclear DYRK1A is a necessary but not sufficient demonstration of its utility as a tool compound in animal models. In order to assess results from in vivo experiments detailed knowledge of the ADME-properties of PST-001 is needed. The pharmacokinetic properties of intravenous administration of PST-001 was investigated in a rat model. A bolus injection of PST-001 at a dose of $1 \mathrm{mg} / \mathrm{kg}$ in the tail vein revealed a maximum venous concentration of $647 \mathrm{ng} / \mathrm{mL}$ after $2 \mathrm{~min}$ (Table 2). The compound rapidly disappeared from circulation with a $\mathrm{t}_{\frac{1}{2}}$ of $43 \mathrm{~min}$. No PST-001 could be found in the urine, indicating that rapid metabolism is the main cause of the short $t_{\frac{1}{2}}$ observed. A separate mouse microsome stability assay of PST-001 showed a half-life $\left(\mathrm{t}_{\frac{1}{2}}\right)$ of $25^{2} \mathrm{~min}$, corresponding to an intrinsic clearance, $C_{\text {int }}$, of $55 \mu \mathrm{L} / \mathrm{min} / \mathrm{mg}$, regarded as high. Bolus injection of PST-001 in the tail vein of a mouse confirmed a rapid clearance from blood plasma with a $\mathrm{t}_{\frac{1}{2}}$ of $0.15 \mathrm{~h}$ and $\mathrm{C}_{\max }$ of $362 \mathrm{ng} / \mathrm{mL}$ obtained $5 \mathrm{~min}$ after the injection. In the mouse model, the PK-parameters were also determined in the brain samples. In the brain $P K, t_{\frac{1}{2}}$ and $T_{\max }$ were identical to the values observed in plasma; however, $\mathrm{C}_{\max }$ were $867 \mathrm{ng} / \mathrm{mL}$, more than the double than in plasma. Oral administration of PST-001 in the mouse model at a fivefold dose compared to 
the IV experiments showed a maximum plasma concentration $\left(C_{\max }\right)$ of $76 \mathrm{ng} / \mathrm{mL}$ after $1 \mathrm{~h}$ $\left(\mathrm{T}_{\max }\right)$ representing a bioavailability, $\mathrm{f}$, of $21 \%$. Samples of brain tissue were taken at the same time-points as the plasma samples and showed that the concentrations of PST-001 in the brain tissue was the double of that of the plasma concentration, hence indicating that PST-001 is transported efficiently across the blood brain barrier both by IV and PO administration (Table 2). Stable oral bioavailability of PST-001 was established through twice-a-day administration in the animal food of $10 \mathrm{mg} / \mathrm{kg}$ of PST-001, giving a steady state brain concentration of $150 \mathrm{ng} / \mathrm{mL}$ and a plasma level of $76 \mathrm{ng} / \mathrm{mL}$ (corresponding to $0.25 \mu \mathrm{M}$ ).

Table 2. In vitro pharmacokinetic (PK) assessment of PST-001 in rat (male Sprague Dowly) or mouse (male C57Bl) following IV or PO administration.

\begin{tabular}{|c|c|c|c|c|c|}
\hline \multirow{2}{*}{$\begin{array}{c}\text { PK } \\
\text { Parameter }\end{array}$} & \multirow[b]{2}{*}{$\begin{array}{l}\text { IV (Plasma) } \\
\text { (Rat) }\end{array}$} & \multirow[b]{2}{*}{$\begin{array}{l}\text { IV Plasma } \\
\text { (Mouse) }\end{array}$} & \multicolumn{3}{|c|}{ Administration Route and Measured Tissue } \\
\hline & & & $\begin{array}{l}\text { IV Brain } \\
\text { (Mouse) }\end{array}$ & $\begin{array}{l}\text { PO Plasma } \\
\text { (Mouse) }\end{array}$ & $\begin{array}{l}\text { PO Brain } \\
\text { (Mouse) }\end{array}$ \\
\hline PST-001 dose & $1 \mathrm{mg} / \mathrm{kg}$ & $1 \mathrm{mg} / \mathrm{kg}$ & $1 \mathrm{mg} / \mathrm{kg}$ & $5 \mathrm{mg} / \mathrm{kg}$ & $5 \mathrm{mg} / \mathrm{kg}$ \\
\hline $\mathrm{t}_{\frac{1}{2}}(\mathrm{~h})$ & 0.72 & 0.15 & 0.15 & NQ & 0.27 \\
\hline $\mathrm{T}_{\max }^{2}(\mathrm{~h})$ & 0.03 & 0.08 & 0.08 & 1.00 & 0.25 \\
\hline $\mathrm{C}_{\max }(\mathrm{ng} / \mathrm{mL})$ & 647 & 362 & 867 & 76 & 153 \\
\hline $\mathrm{AUC}_{\mathrm{all}}(\mathrm{h} * \mathrm{ng} / \mathrm{mL})$ & 158 & 84 & 200 & 89 & 189 \\
\hline CL (mL/h/kg) & 6281 & 11865 & 4989 & & \\
\hline $\mathrm{Vd}(\mathrm{mL} / \mathrm{kg})$ & 2387 & 1388 & 553 & & \\
\hline $\mathrm{f}$ & & & & $21.2 \%$ & \\
\hline
\end{tabular}

The results from the pharmacokinetic study of PST-001 in rats suggests rapid metabolism may be the cause of the short $t_{\frac{1}{2}}$ observed. Effective transport to the brain acting as a reservoir may also contribute to the rapid plasma clearance of PST-001. A short $t_{\frac{1}{2}}$ is in itself not detrimental to animal studies, but a rapid metabolism creating metabolites with on- or off-target effects would handicap interpretation of the results. Hence, we included studies of which metabolites are formed at what amounts, along with their DYRK1A activities. First an in silico assessment of the site and type of cytochrome p450 (Cyp) metabolism was undertaken using the SMARTcyp [36] and GLORY [37,38] metabolite prediction services. SMARTcyp predicted that the three main sites for Cyp-metabolism were the C-5 methoxy methyl, the benzothiazole sulfur atom and the methyl group of the acetamido moiety. These predictions were further substantiated by the GLORY metabolism webservice, where the three most probable metabolites were predicted to be the demethylated 5-hydroxy-analog of PST-001, hydroxylation of the acetamide methyl group yielding the glycolic amide derivative of PST-001 and oxidation of the benzothiazole sulfur atom. To test the in silico predictions, PST-001 was subjected to a $1 \mathrm{~h}$ treatment with rat liver microsomal fraction (RLM) [39]. A high-resolution LCMS target analysis verified the presence of the suggested metabolites. The analysis was performed using an internal standard allowing for calculation of the mass balance in the metabolism study. The sum of all analytes (PST-001 and the suggested metabolites) was close to $100 \%$, suggesting that the set of identified metabolites represents a quantitative picture of the metabolism of PST-001. As shown in Figure 5, the metabolism takes place through two different primary processes; Oxidation of PST-001 (S-oxidation or acetamido hydroxylation, which are indistinguishable by mass spectrometry) forming molecules with the formula $\mathrm{C}_{15} \mathrm{H}_{13} \mathrm{~N}_{3} \mathrm{O}_{3} \mathrm{~S}$ or hydrolysis of the acetamido group (deacetylation) forming compound 1. The latter process is likely not a Cyp reaction, but rather a result of protease activity in the RLM fraction. The predicted demethylated metabolite of PST-001 predicted by SMARTcyp was not detected. The primary metabolites (oxidation metabolite $\mathrm{C}_{15} \mathrm{H}_{13} \mathrm{~N}_{3} \mathrm{O}_{3} \mathrm{~S}$ and compound 1) were further metabolized to secondary metabolites by deacetylation or oxidation, respectively forming a secondary metabolite with formulas $\mathrm{C}_{13} \mathrm{H}_{11} \mathrm{~N}_{3} \mathrm{O}_{2} \mathrm{~S}$. Compound $\mathbf{1}$ is also metabolized by a demethylation to compound 2 . The final metabolite(s) is a compound with formula 
$\mathrm{C}_{12} \mathrm{H}_{9} \mathrm{~N}_{3} \mathrm{O}_{2} \mathrm{~S}$ where all three processes had taken place. The investigated metabolite mixture had satisfactory mass balance indicating that the major metabolites and pathways have been identified.

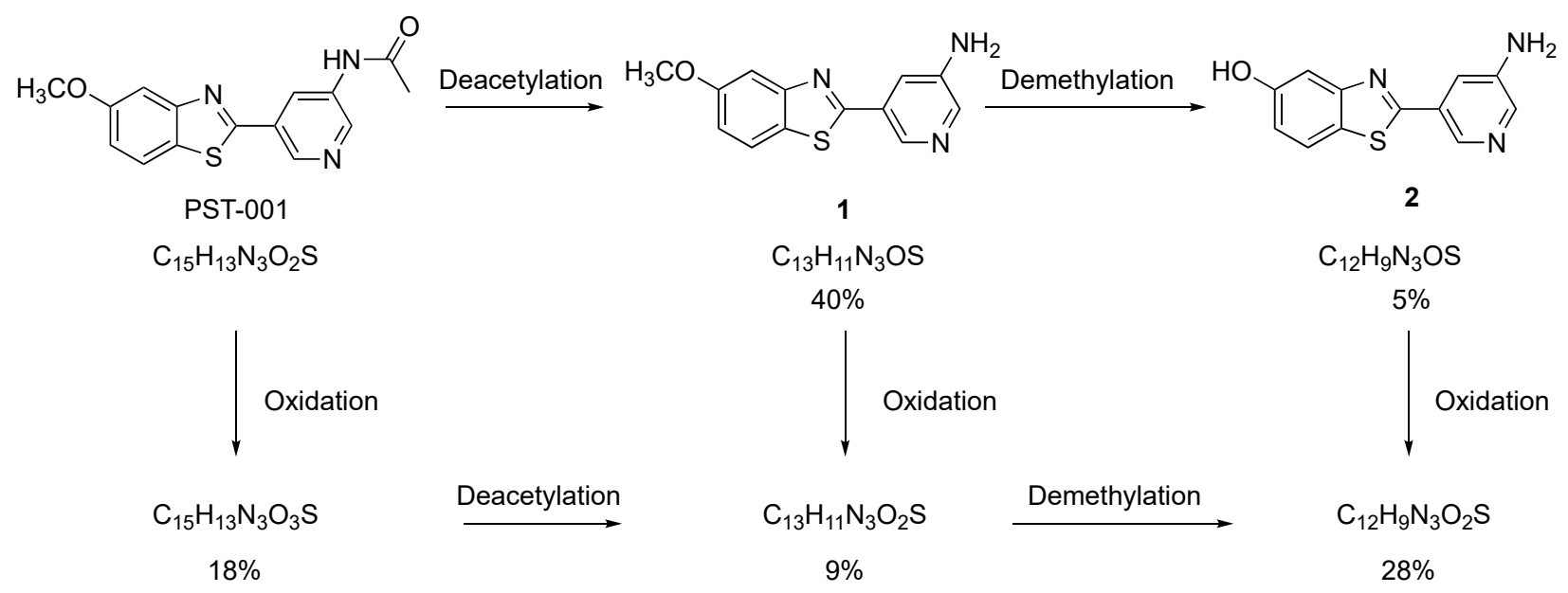

Figure 5. Identified metabolic pathways of PST-001. The percentages represent a snapshot of the distribution of the metabolites at a $30 \%$ conversion of PST-001.

It is also highly likely that several of the metabolites are active inhibitors of DYRK1A. Deacetylation to compound 1, an intermediate in the preparation of PST-001, was profiled in the protein kinase panel and showed high selectivity towards DYRK1A and inhibitory activity similar to PST-001. The X-ray structure of PST-001 does not show any critical interaction with the acetyl group (Figure 3); and deacetylation would not significantly change the hydrogen bond donor capacity of the amino group. Similarly, potential acetamido hydroxylation would not eliminate essential interactions, and the additional hydroxyl group could be hydrogen bonded to water or polar protein groups. Compound $\mathbf{2}$ formed by demethylation of compound 1 may seem more likely to change binding properties, since this changes the details of critical hinge H-bond interactions with Leu241NH. However, our previous studies of fragments bound to DYRK1A included direct comparisons of 5-methoxy- and 5-hydroxybenzothiazole compounds. These indicate that the desmethyl metabolite of PST-001 would likely show similar activity against DYRK1A [27].

Considering the interactions of the inhibitor with the DYRK1A target (Figure 3), only the possible oxidation of the sulfur atom would be clearly disruptive to binding by disabling the sulfur- $\pi$ interaction that is key to the selective and efficient binding to the target protein kinase. The total amount of oxidated metabolites is approximately $50 \%$ representing an upper limit of metabolites where the target affinity may be more compromised.

Given that PST-001 is orally active, allowing stable plasma levels in mice to be obtained by normal feeding, a dose escalation study was performed in order to secure an effective dose of PST-001 in the brain of the Ts65Dn mice. The mice were fed with a mouse-palatable food mixture containing $35 \mathrm{mg}, 50 \mathrm{mg}$, and $100 \mathrm{mg}$ PST-001/ $\mathrm{kg}$ powdered food and the steady state level in the liver and the brain was monitored by LC/MS. The highest dose provided a continuous concentration of $1.25 \mu \mathrm{mol} / \mathrm{g}$ both in the liver and in the brain and was used in fear conditioning experiments. There was no difference in the PST-001 concentration between control and Ts65Dn mice (Figure 6). This was confirmed by Two-way analysis of variance (ANOVA), which did not detect any significant genotype $(\mathrm{F}(1,36)=0.0061, p=0.9380)$ or tissue $(\mathrm{F}(1,36)=0.3706, p=0.5465)$ effects on the measured PST-001 concentrations. 


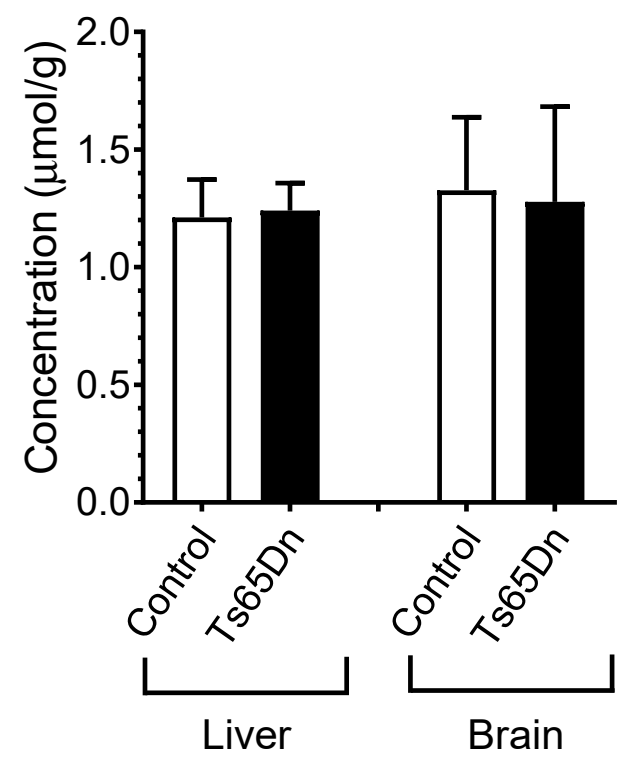

Figure 6. Levels of PST-001 found in the brain and in plasma after completion of the fear conditioning experiment.

The capacity for contextual memory of 10- to 16-week old Ts65Dn mice was compared with age-matched euploid control mice using a fear conditioning protocol [40]. Briefly, the mice were exposed for $3 \mathrm{~min}$ to the context test chamber serving as a conditioning stimulus, followed by an electric shock for $2 \mathrm{~s}$ representing the unconditioned stimulus. The memory test was performed $24 \mathrm{~h}$ later, by re-exposing the mice to the same context. Freezing, defined as a species-specific defensive reaction characterized by lack of movement besides respiration and heartbeat, associated with crouching posture, was used as a measure of learning, and assessed for $180 \mathrm{~s}$, every $9 \mathrm{~s}$ by two trained observers aware of the mouse genotypes and the pharmacological agent being used.

As can be seen in Figure 7, PST-001-treated Ts65Dn mice displayed freezing at a comparable percentage to both placebo-treated (food mix without PST-001) and PST-001-treated control euploid animals. We also performed parallel preliminary tests of the combination of a chronic treatment of PST-001, as described above, and two acute I.P. injections of memantine hydrochloride ( $5 \mathrm{mg} / \mathrm{kg}$ of mouse weight) $15 \mathrm{~min}$ before shock exposure and $15 \mathrm{~min}$ before exposure to the context chamber $24 \mathrm{~h}$ later. The mechanism of action of PST-001 is expected to be different from the mechanism of action of the drug memantine, and one could potentially envision a scenario in which both PST-001 and memantine might be used together in the same individual. In these preliminary tests we observed that PST-001 treatment, even when in combination with memantine, eliminated the learning and memory deficits displayed by Ts65Dn mice as assessed by contextual fear conditioning.

Factorial ANOVA (performed with Statistica Academic version 13, TIBCO Sofware, Palo Alto, CA) revealed that both genotype $(\mathrm{F}(1,46)=6.8950, p=0.0117)$ and drug treatment $(\mathrm{F}(2,46)=4.2587, p=0.0201)$ had significant effects on the percentage of freezing during the context test. In addition, a significant interaction between genotype and drug treatment was detected $(F(2,46)=4.5596, p=0.0156)$, which indicate a genotype-dependent drug response. Post hoc (Fisher LSD) tests confirmed that, between the two groups that had the food mixture without any medication, euploid control mice displayed a significantly larger percentage of freezing during the context test than Ts65Dn mice $(p=0.0007)$. In contrast, Ts65Dn mice that received PST-001 treatment showed no significant difference in freezing behavior compared with untreated control ( $p=0.9107)$ or PST-001-treated control mice $(p=0.5517)$. Therefore, PST-001 completely eliminated the learning and memory deficits displayed by Ts65Dn mice as assessed by contextual fear conditioning. Interestingly, this compound produced no detectable effects on the percentage of freezing behavior displayed by control euploid mice $(p=0.4815)$. Post hoc tests also showed that Ts65Dn mice that 
received combined PST-001 and memantine treatment showed no significant difference in freezing time compared with untreated control $(p=0.6708)$, PST-001-treated control mice $(p=0.8855)$, or control mice treated with combined PST-001 and memantine $(p=0.1190)$.

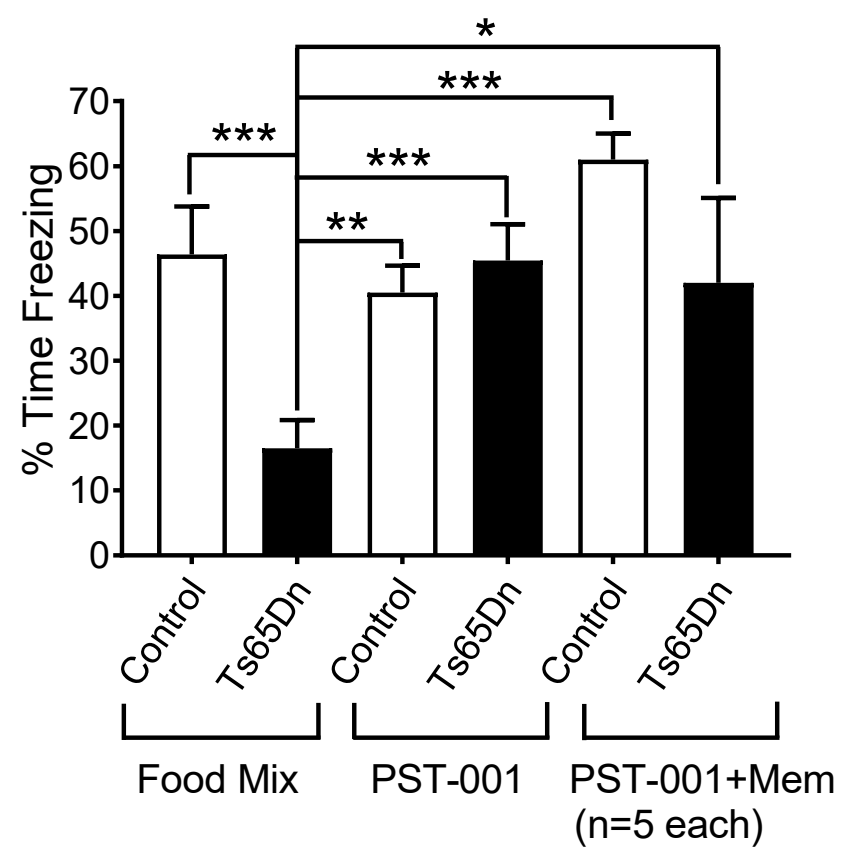

Figure 7. Contextual fear conditioning model. Parallel experiments showing the effect of PST-001 in the food on the freezing time in the contextual fear conditioning model and the combined effect of PST-001 in the food and acute memantine injections. Data represent mean \pm SEM and statistical significance is expressed as ${ }^{*}, *$ and ${ }^{* * *}$, for $p<0.05, p<0.01$, and $p<0.001$, respectively.

Preclinical experiments of the effects of compound PST-001 in the mouse model of DS Ts65Dn demonstrated that the compound is well tolerated by these mice and that chronic oral administration of PST-001 eliminates context discrimination behavioral deficits. We have confirmed the oral availability and brain penetration of this compound in mice. Preliminary experiments involving the co-administration of PST-001 and memantine failed to show additive or antagonistic interactions between these two pharmacological agents.

\section{Discussion}

The protein kinase DYRK1A has in the last decade moved from relative obscurity to become a widely studied potential target for drug development. DYRK1A regulates important cellular processes, in particular proliferation and differentiation of neuronal progenitor cells [41], as well as neurodegeneration [42]. It is thus no surprise that neurological syndromes and disorders such as DS [14,34,43-54], Alzheimer's disease [44], Parkinson's [55-57], and Pick's disease [58] all involve abnormal expression of DYRK1A [59]. Abnormal DYRK1A expression is also linked to a raft of malignancies like glioblastoma multiforme [60], gastrointestinal stromal tumors, lung cancer [61], melanoma, and leukemias (AML, AMLK, and ALL) [62]. Furthermore, DYRK1A may represent a target for the treatment of diabetes Type 1 and 2, as the kinase is involved in pancreatic $\beta$-cell proliferation [63].

As a consequence of the increased interest in therapeutic modification of DYRK1A activity, a wide range of inhibitors has been reported. Few of these inhibitors have an established selectivity profile, which limits their utility as tool compounds. Furthermore, reliable molecules for animal studies must also have acceptable and known pharmacokinetic properties, preferably including good blood-brain passage, for reliable interpretation of results.

The first DYRK1A inhibitor tested in animal models was INDY, developed by Ogawa et al. [25] INDY showed effects in biochemical and cellular models and was also applied on $X$. laevis embryos with $x D Y R K 1 A$ overexpression-induced deformity, where the 
compound rescued the deformity in the eye and head of the embryos. The next inhibitor tested was epigallocatechin-3-gallate (EGCG). In 2009, it was reported that major features of partial trisomy of MMU16 (a model of HSA21 trisomy) found in transgenic phenotype mice overexpressing DYRK1A could be rescued by feeding these animals with polyphenol-based diets from gestation to adulthood [24]. In 2014, a green tea extract was administered to Ts65Dn mice for a month, and supposedly the EGCG contained in the extract normalized the DYRK1 activity in hippocampus, and significantly improved their performance in the Morris water maze test [23]. However, although the authors did find signals of improved cognition in a pilot clinical trial, the effect sizes of these improvements were small, and were not statistically significant without a concomitant cognitive training program being applied to the study participants [64]. The tool compounds GNF7156 and GNF4877 used in a study of induction of beta-cell proliferation are non-selective DYRK1A and GSK3 $\beta$ inhibitors making interpretation of the results difficult [65].

A recent review characterizes the main challenges of pharmacologically inhibiting DYRK1A and targeting trisomy as the bridging of two knowledge gaps: (1) the lack of understanding of the downstream targets of excessive DYRK1A activity leading to the typical phenotypic signs of trisomy 21; and (2) the bioavailability, specificity, and dosedependent inhibition of DYRK1A by candidate inhibitors must be ascertained for specific tissues, and correlations between pharmacological actions and therapeutic outcomes need to be established [66]. With this background, we designed PST-001 as a tool compound for studying in vivo effects of DYRK1A inhibition. The important design criteria include high target activity, high specificity with few and well characterized off-target binding, ability to reach the DYRK1A target in the relevant tissue, including the brain and being able to administer perorally.

PST-001 is a molecule designed to be a selective DYRK-family inhibitor. The benzothiazole part originates from the finding that luciferin is an inhibitor for a select few protein kinases [26], in particular the DYRK-family, but also CK2, Aurora A and B as well as CDK2/Cyclin A. The effects of substitutions pattern on the benzothiazole ring were explored using a series of 2-acetamidobenzothiazole fragments and an explanation for the unusual high DYRK-selectivity was offered in a subsequent experiment [27]. The key to the uncommon selectivity of the fragment sized molecules was proposed to be an interaction between the benzothiazole sulfur atom and F238 through a sulfur- $\pi$ interaction. The selectivity of these short fragments was surprisingly high, strongly favoring the intended target, but the on-target potency was inadequate and had to be increased for the compounds to be applicable tool compounds for in vivo studies. Examination of the structures from X-ray crystallographic studies pointed out that the fragments should be longer to span the active site of DYRK1A from the hinge to Lys188. Inspired by the binding mode of the analogous benzothiazole derivative, luciferin, which does span the active site via its additional dihydrothiazole ring, it was decided to lengthen the benzothiazole fragment by using a heteroaromatic structure, including the choice of a heteroatom to interact with Lys188. A meta-substituted pyridine ring was selected on the basis that the basic nitrogen atom in the pyridine ring would work as an acceptor to the lysine side chain ammonium ion. Furthermore, a meta-relationship between the benzothiazole and the pyridine nitrogen atom would place the nitrogen in a geometrically advantageous position for an interaction with the ubiquitous Lys-residue. Finally, an acetamido group was introduced in the other meta-position of the pyridine ring to interact with Asp307, and thereby securing the orientation of the pyridine nitrogen "inwards", facing Lys188. The presence of two lipophilic residues, Leu294 and Val308 creates a lipophilic floor in the DYRK1A ATP-binding pocket fitting snugly to the lipophilic aromatic core of PST-001. PST-001 showed high potency against DYRK1A and retained the unusually high selectivity typical for the benzothiazole fragments. Importantly, the kinase profiling revealed that there is no discernible activity against GSK3 $\beta$ at concentrations where DYRK1A is fully inhibited, a common limitation known from typical DYRK1A inhibitors such as INDY [25] and the leucettamine derivative L41 [67].

DYRK1A is an intranuclear protein kinase and tends to accumulate in nuclear structures [68]. Transport across cellular and nuclear membranes is thus a critical requirement 
for effective inhibitors One of the intranuclear targets for DYRK1A phosphorylation is the nuclear transcription factor NFATc1 [69]. The established NFAT/calcineurin reporter system is thus an appropriate choice for monitoring the intranuclear activity of DYRK1A [34]. We adapted the HEK-cell reporter system and showed that PST-001 has the ability to pass the cellular envelope as well as entering the cell nucleus and inhibit intranuclear DYRK1A.

The next level of complexity for a successful in vivo model is to ensure that the inhibitor reaches the intended tissue where the effect is expected to take place. Regarding the pharmacological effects of DYRK1A inhibition, the intended tissue may vary from inside the brain as in the case of neurodegenerative diseases and CNS cancers such as GBM, via the pancreas for $\beta$-cell proliferation, to the general circulation for metastatic cancers in the lungs and intestines. It is hence important to establish the pharmacokinetics of the inhibitors in relevant animal models, as well as gaining insight regarding key ADME parameters in the animal model.

Upon administration of PST-001 to the animal (typically a rodent like a mouse or a rat), either through an IV or PO route, the pharmacokinetic measurements reveal that the molecule is rapidly distributed in plasma, with a $\mathrm{T}_{\max }$ of $2 \mathrm{~min}$ and $15 \mathrm{~min}$ for IV and PO administration, respectively. Peroral administration is effective and approximately $25 \%$ of the IV-plasma $\mathrm{C}_{\max }$ can be obtained through a PO administration of the same dose. The lifetime of the molecule in plasma is short, however, with $t_{1 / 2}$ in the range of less than $1 \mathrm{~h}$. On the other hand, brain penetrance is good, with brain levels reaching $50 \%$ of the plasma level at $\mathrm{T}_{\max }$ after $\mathrm{PO}$ administration.

As indicated by the short $t_{1 / 2}$, PST-001 is rapidly metabolized to defined metabolites, all of which may be active inhibitors against the DYRK1A target.

As a proof of concept, an in vivo study in Ts65Dn mice was undertaken. The end point of this study was improvement in learning and memory, as measured by the animals' performance in a context discrimination task. A continuous feeding of $100 \mathrm{mg}$ PST-001/kg in the animal food produced a steady state level of $1.25 \mu \mathrm{mol} / \mathrm{g}$ PST-001 in both plasma and brain tissue in control mice as well as Ts65Dn mice. Before the contextual fear conditioning experiments, all mice were exposed for three-days to either food mixture alone or food mixture with added PST-001, and exposure continued during the experiment.

The contextual fear experiments showed that there is a large and statistical difference in learning and memory between control euploid mice and Ts65Dn mice, but that the learning and memory ability of the Ts65Ds mice could be rescued upon PO administration of PST-001. Furthermore, the data showed no indication of additive or antagonistic effects between PST-001 and the anti-Alzheimer drug memantine, suggesting that the effect of PST-001 acts at different time scale and through different mechanisms than memantine. Obviously, in the absence of in vivo/preclinical evidence of DYRK1A inhibition by PST-001, we cannot guarantee that the pharmacological rescuing of contextual fear conditioning in Ts65Dn mice is necessarily due to DYRK1A inhibition in these mice. Future experiments involving enzyme inhibition or modifications of downstream targets in samples from the treated mouse should provide a key causal link between in vivo/preclinical DYRK1A inhibition and the behavioral effects of PST-001 in this mouse model of DS.

\section{Materials and Methods}

\subsection{Chemical Preparation}

All reagents and solvents were obtained from commercially available sources and were used without further purification. All isolated compounds are $>95 \%$ pure by HPLC. Procedures for preparing 5-Methoxybenzothiazole as well as original spectra and chromatograms are compiled in the SI-section.

5-(5-Methoxybenzo[d]thiazol-2-yl)pyridin-3-amine (1). 5-Methoxybenzothiazole (6.34 g, $38.4 \mathrm{mmol})$, 3-amino-5-bromopyridine $(7.41 \mathrm{~g}, 42.8 \mathrm{mmol})$, cesium carbonate $(12.5 \mathrm{~g}$, $38.4 \mathrm{mmol})$, copper(I)bromide $(1.12 \mathrm{~g})$ and $\mathrm{Pd}(\mathrm{OAc})_{2}(0.56 \mathrm{~g}, 2.50 \mathrm{mmol})$ were suspended in dry DMF $(200 \mathrm{~mL})$ under argon. $\mathrm{P}(t-\mathrm{Bu})_{3}(1.00 \mathrm{~g}, 4.94 \mathrm{mmol})$ dissolved in $10 \mathrm{~mL}$ dry DMF was added. The reaction mixture was heated at $150{ }^{\circ} \mathrm{C}$ for $1.5 \mathrm{hrs}$, cooled to room 
temperature and poured into EtOAc $(100 \mathrm{~mL})$. The organic phase was washed with water $(100 \mathrm{~mL})$ and the aqueous phase extracted with EtOAc $(2 \times 100 \mathrm{~mL})$. The combined organic phase was washed with water, dried $\left(\mathrm{MgSO}_{4}\right)$, filtered and concentrated. Flash chromatography (Heptane: EtOAc 80: 20-50: 50-EtOAc) afforded $4.09 \mathrm{~g}$ (41\%) of the title compound as a pale yellow solid. Purity $>95 \%$ (HPLC). ${ }^{1} \mathrm{H}$ NMR $\left(300 \mathrm{MHz}, \mathrm{DMSO}-d_{6}\right)$ $\delta 8.39(\mathrm{~s}, 1 \mathrm{H}), 8.08(\mathrm{~s}, 1 \mathrm{H}), 8.01(\mathrm{~d}, J=8.8,1 \mathrm{H}), 7.73-7.49(\mathrm{~m}, 2 \mathrm{H}), 7.11(\mathrm{dd}, J=8.8,2.5$, $1 \mathrm{H}), 5.71(\mathrm{~s}, 2 \mathrm{H}), 3.87(\mathrm{~s}, 3 \mathrm{H}) . \mathrm{MS}(\mathrm{pos}): 258(\mathrm{M}+\mathrm{H}), \mathrm{HR}(\mathrm{M}+\mathrm{H}): 258.0695$ (observed), 258.0701 (calculated).

N-(5-(5-Methoxybenzo[d]thiazol-2-yl)pyridin-3-yl)acetamide (PST-001) [70]. To a suspension of 5-(5-methoxybenzo[d]thiazol-2-yl)pyridin-3-amine $(1.29 \mathrm{~g}, 5.00 \mathrm{mmol})$ in DCM $(25 \mathrm{~mL})$ was added pyridine $(10 \mathrm{~mL})$, followed by acetic anhydride $(0.95 \mathrm{~mL}, 10.0 \mathrm{mmol})$. The reaction mixture was stirred at room temperature overnight, poured into water $(100 \mathrm{~mL})$ and the aqueous phase extracted with $\mathrm{CHCl}_{3}: \mathrm{MeOH}(90: 10)(3 \times 100 \mathrm{~mL})$. The combined organic extract was dried $\left(\mathrm{Na}_{2} \mathrm{SO}_{4}\right)$, filtered and concentrated. The crude material was treated with EtOAc $(75 \mathrm{~mL})$, sonicated for $2 \mathrm{~min}$, and filtered. Drying allowed the isolation of $1.30 \mathrm{~g} \mathrm{(73 \% )} \mathrm{of} \mathrm{the} \mathrm{title} \mathrm{compound} \mathrm{as} \mathrm{a} \mathrm{beige} \mathrm{solid} \mathrm{from} 1.54 \mathrm{~g}$ substrate. Purity $99.5 \%$ (HPLC). ${ }^{1} \mathrm{H}$ NMR (400 MHz, DMSO- $\left.d_{6}\right) \delta 10.41(\mathrm{~s}, 1 \mathrm{H}), 8.88(\mathrm{~s}, 1 \mathrm{H}), 8.80(\mathrm{~s}, 2 \mathrm{H}), 8.03$ $(\mathrm{d}, J=8.8,1 \mathrm{H}), 7.66(\mathrm{~d}, J=2.3,1 \mathrm{H}), 7.13(\mathrm{dd}, J=8.8,2.4,1 \mathrm{H}), 3.87(\mathrm{~s}, 3 \mathrm{H}), 2.13(\mathrm{~s}, 3 \mathrm{H}) .{ }^{13} \mathrm{C}$ NMR $(150 \text { MHz, DMSO-d })_{6} \delta 169.8,165.8,159.5,155.2,142.8,142.2,136.8,129.3,126.7,123.5$, 123.2, 116.3, 106.1, 56.0, 24.4. IR (ATR, $\mathrm{cm}^{-1}$ ): 3301, 1680, 1603, 1551, 1503. MS (pos): 322 (M+Na), HR (M+H): 300.0801 (observed), 300.0807 (calculated).

\subsection{DYRK1A Protein Production and Crystallization}

DYRK1A comprising the kinase domain (DYRK1A, residues 126-490) was produced in bacteria as a HIS-tagged fusion protein and purified as described in detail by Alexeeva et al. [71].

Co-crystallization with the PST-001 followed the protocol described by Alexeeva et al. In short, the protein kinase DYRK1A was concentrated to 7-10 mg/mL and mixed with the inhibitor solution in DMSO to achieve an approximately 10-50-fold molar excess of the inhibitor. The crystallization solution (100 mM potassium thiocyanate, $50-100 \mathrm{mM}$ $\mathrm{NaCl}$ or $\mathrm{KCl}, 10-16 \%$ PEG 3350) gave octahedron-shaped crystals within 5-7 days at room temperature. Crystals were cryoprotected in crystallization solution modified to include $30 \%$ ethylene glycol and were flash cooled in liquid nitrogen.

\subsection{Structure Solution and Refinement}

X-ray diffraction data were collected at the Berlin Electron Storage Ring, BESSY II, at the Helmholz Zentrum Berlin, Germany. The images were integrated using the XDSapp 2.0 software [72] and XDS (version 31 January 2020) [73]. The structures were solved by molecular replacement with Phaser [74] using the DYRK1A structure with PDB code 4NCT [71] as search model. The structures were refined by iterative cycles of PHENIX [75] and the CCP4 [76] program REFMAC5 [77] followed by the manual refitting of residues and inhibitors into the electron-density between the refinement cycles and placement of water molecules using Coot v.0.7.2. PRODRG [78] was used to generate the cif-files for inhibitors.

\subsection{IC $_{50}$ Determination}

The principal method utilized is a radioactive filter binding assay using ${ }^{33} \mathrm{P}$ ATP $[79,80]$. The compounds were diluted to the appropriate concentration. The compounds were added to a "mother plate" consisting of samples, controls, and blanks. These serve as the source for "daughter plates" which are stored at $-20{ }^{\circ} \mathrm{C}$ until assay initiation. Protein Kinases: Enzyme/Substrate mixture was added to the compound, and the compounds were incubated for five minutes at room temperature (RT). ${ }^{33} \mathrm{P}$ ATP was added to the compounds to initiate the assay. Orthophosphoric acid was added to the compounds to halt the assay. Assay components were harvested onto P81 filter plates, filter plates were air-dried, scintillation fluid was added to plates, and counts were read on a Topcount NXT. A mean percentage activity was calculated. 


\subsection{Kinase Profile of Benzothiazolylpyridine Derivatives}

The determination of protein kinase inhibition was performed at the International Centre for Kinase Profiling at the University of Dundee, UK. The method used is a radioactive filter binding assay using ${ }^{33} \mathrm{P}$ ATP as described in the literature [79]. The ATP concentrations were at or below the calculated $\mathrm{K}_{\mathrm{m}}$ for ATP for each particular kinase.

\subsection{Luciferin/Luciferase Detected NFAT-Calcineurin Assay of Cellular Effect of DYRK1A}

This method was earlier described in Czarna et al. 2018 [81]. For the measurement of the PST-001 inhibitor: HEK293 (ECACC catalog number 85120602) NFAT reporter gen cell lines were cultivated for $24 \mathrm{~h}$ without doxycycline before they were stimulated with $1 \mu \mathrm{M}$ ionomycin and $10 \mathrm{nM}$ PMA for $24 \mathrm{~h}$ in presence of the indicated concentration of the PST-001 inhibitor. Renilla luciferase activity was measured in a luminometer. Luciferase activity in the control sample was arbitrary set as 1 and the other values are correlated to this with standard error of the mean $(n=3)$. All experiments were performed in triplicates.

\subsection{Rat IV Pharmacokinetics}

Male Sprague-Dawley rats (surgically prepared with jugular vein cannulation) were administered PST-001 (1 mg/kg; vehicle 10\% dimethyl sulfoxide $90 \%$ 2-hydroxypropyl$\beta$-cyclodextrin ( $20 \% w / v$ in PBS)) intravenously by bolus to tail vein at a dose volume of $1 \mathrm{~mL} / \mathrm{kg}$. For determining plasma pharmacokinetics blood samples (via cardiac puncture into heparinized tubes and centrifuged for plasma at $4{ }^{\circ} \mathrm{C}$ ) were serially sampled via jugular vein at 2, 0.5, 5, 15, and $30 \mathrm{~min}, 1,2,4,8$, and $24 \mathrm{~h}$ timepoints post dosing. Three animals per timepoint were sampled. All samples were stored at $-20^{\circ} \mathrm{C}$ pending analysis. Bioanalysis was carried out by UHPLC-TOF mass spectrometry using electrospray ionization against matrix matched calibration lines. The pharmacokinetic parameters were subsequently calculated by noncompartmental methods.

\subsection{Mouse PO Pharmacokinetics}

Male C57BL/ 6 mice were administered PST-001 ( $5 \mathrm{mg} / \mathrm{kg}$; vehicle $10 \%$ dimethyl sulfoxide $90 \%$ 2-hydroxypropyl- $\beta$-cyclodextrin ( $20 \% w / v$ in PBS)) orally by gavage at a dose volume of $10 \mathrm{~mL} / \mathrm{kg}$. For determining plasma and brain pharmacokinetics blood samples (via cardiac puncture into heparinized tubes and centrifuged for plasma at $4{ }^{\circ} \mathrm{C}$ ) and brains were terminally sampled at $0.25,0.5,1,2,3,4,6$, and $8 \mathrm{~h}$ timepoints post dosing. Three animals per timepoint were sampled. The three animals designated for the $8 \mathrm{~h}$ timepoint were housed in a metabolism cage post-dosing for collection of urine. All samples were stored at $-20^{\circ} \mathrm{C}$ pending analysis. Bioanalysis was carried out by UHPLC-TOF mass spectrometry using electrospray ionization against matrix matched calibration lines.

The pharmacokinetic parameters were subsequently calculated by noncompartmental methods.

\subsection{Bioanalysis}

Samples are prepared by protein precipitation and/or dilution: tissues are homogenized first. Analysis is carried out using a generic internal standard, with matrix-matched calibration standards bracketing the study samples.

Samples were analyzed by high resolution accurate mass UHPLC-TOF MS. The LC-MS system comprised an Agilent 1290 Infinity UHPLC pump with an Agilent 1290 Infinity HTS autosampler, coupled with an Agilent $6550 \mathrm{iFunnel} \mathrm{QToF} \mathrm{mass} \mathrm{spectrometer,} \mathrm{equipped}$ with a Waters Acquity BEH Phenyl UPLC column, $(50 \times 2.1) \mathrm{mm}, 1.7 \mu \mathrm{m}$ particle size. The mass spectrometer was operated in full scan mode, with positive ion electrospray data acquired over the $m / z$ mass range 100-1000.

\subsection{Ts65Ds Model of Cognition. Determination of Blood, Liver, and Brain PST-001 Concentrations}

To determine the necessary amount of added PST-001 in food to reach a serum concentration consistent with the DYRK1A inhibitory potency of this compound, a GC/MS-based procedure was used. Six control euploid mice of the same genetic background as the Ts65Dn mice were used to perform this analysis; two mice per dose and three doses tested [82]. 
An adapted LC/MS protocol was used for concentration determination of PST-001 in various murine tissues, such as liver and brain.

\subsection{Ts65Ds Model of Cognition. Contextual Fear Conditioning}

The capacity for contextual memory of 10- to 16-week-old Ts65Dn mice was compared with age-matched euploid control mice using the same fear conditioning protocol used in a previous work with the drug memantine [40]. Briefly, the mice were exposed for $3 \mathrm{~min}$ to the context (Med Associates, St. Albans, VT, Modular Mouse Test Chamber) serving as a conditioning stimulus, followed by an electric shock ( $2 \mathrm{~s}, 0.7 \mathrm{~mA}$, constant electric current) representing the unconditioned stimulus. The memory test was performed $24 \mathrm{~h}$ later, by re-exposing the mice to the same context. Freezing, defined as a species-specific defensive reaction characterized by lack of movement besides respiration and heartbeat, associated with crouching posture, was used as a measure of learning, and assessed for $180 \mathrm{~s}$, every $9 \mathrm{~s}$ by two trained observers aware of the mouse genotypes and the pharmacological agent being used. The mean number of observations indicating freezing behavior was expressed as percentage of freezing in relation to the total number of observations. All experiments were video-recorded, for automated video-analysis, confirmation of the trained-observer scores, and archival purposes.

Prior to contextual fear conditioning experiments, all mice were exposed for threedays to either food mixture alone or food mixture with added PST-001. In addition, the mice continued to consume these same food preparations during the two days necessary to perform the behavioral testing. For the chronic administration of PST-001, the following groups were used: (1) euploid control mice exposed to food mixture with no PST-001 ( $n=11)$; (2) control mice exposed to food mixture with PST-001 $(n=10)$; (3) Ts65Dn mice exposed to food mixture with no PST-001 $(n=10)$; and (4) Ts65Dn mice exposed to food mixture with PST-001 $(n=11)$. These animals were killed after the experiments, and their livers and brains were harvested for PST-001 concentration determinations. Comparisons between group means were done with Two-way factorial ANOVA, and Fisher protected least significant difference (PLSD) post hoc test was performed for all significant ANOVA (using Statistica version 13, Tibco Software, Palo Alto, CA, USA).

\section{Conclusions}

PST-001 is an effective and selective DYRK1A inhibitor with proven peroral bioavailability in rodent models. The PK-profile of PST-001 is characterized and sufficiently good to enable clear effects in an animal model. The compound should hence be a valuable addition to the arsenal of DYRK1A inhibitors compatible with in vivo studies, in particular where selectivity towards GSK3 $\beta$ is required.

Supplementary Materials: The following are available online at https:/ /www.mdpi.com/article/10 $.3390 / \mathrm{ph} 14111170 / \mathrm{s} 1$, Figure S1: ${ }^{1} \mathrm{H}$ NMR spectrum (DMSO-d 6 ) of 1-(3-Methoxyphenyl)thiourea, Figure S2: ${ }^{1} \mathrm{H}$ NMR spectrum (DMSO- $\mathrm{d}_{6}$ ) of 5-Methoxybenzo[d]thiazol-2-amine, Figure S3: ${ }^{1} \mathrm{H}$ NMR spectrum $\left(\mathrm{CDCl}_{3}\right)$ of 5-Methoxybenzo[d]thiazole, Figure S4: ${ }^{1} \mathrm{H}$ NMR spectrum (DMSO-d $\left.{ }_{6}\right)$ of 5-(5methoxybenzo[d]thiazol-2-yl)pyridin-3-amine (1), Figure S5: ${ }^{1} \mathrm{H}$ NMR spectrum (DMSO- $\mathrm{d}_{6}$ ) of $\mathrm{N}-(5-$ (5-Methoxybenzo[d]thiazol-2-yl)pyridin-3-yl)acetamide (PST-001), Figure S6: HPLC-chromatogram of N-(5-(5-Methoxybenzo[d]thiazol-2-yl)pyridin-3-yl)acetamide (PST-001) showing a purity of $>99 \%$. Table S1: Crystallographic data and model statistics for 6YF8., Table S2: Remaining protein kinase activity after exposure to PST-001 and compound 1. Two concentrations of the inhibitor were used, 100 and $1 \mu \mathrm{M}$.

Author Contributions: Conceptualization, W.S., A.F. and J.S.M.S.; methodology, W.S., A.C.S.C. and R.A.E.; formal analysis, W.S., U.R. and A.C.S.C.; investigation, I.B., M.R.S.; data curation, U.R. and A.C.S.C.; writing—original draft preparation, W.S. and J.S.M.S.; writing—review and editing, R.A.E., W.S. and A.C.S.C.; project administration, J.S.M.S.; funding acquisition, A.F. All authors have read and agreed to the published version of the manuscript.

Funding: This research was funded by the Norwegian Research Council, grant number 245619. 
Institutional Review Board Statement: Ts65DS mouse model: The study was carried out in compliance with the ARRIVE guidelines and in accordance with the Guide for the Care and Use of Laboratory Animals (National Institutes of Health, 2011). The study was approved by the Institutional Animal Care and Use Committee (IACUC) at Case Western Reserve University (CWRU) (protocol number 2016-0013, approval date 16 February 2016). In vivo pharmacokinetic study: The study was approved by the UK Home Office under the Pharmidex Project Licence number P651A96A4.

Data Availability Statement: The atomic co-ordinates and structure factors for DYRK1A with the inhibitor PST-001 has been deposited in the Protein Data Bank under PDB accession code 6YF8 https:/ / www.rcsb.org/structure/6YF8.

Acknowledgments: The authors like to thank Pharmidex Inc. for expertly performing pharmacokinetic measurements.

Conflicts of Interest: W.S., J.S.M.S., U.R. and A.F. are, or have been, employed by Pharmasum Therapeutics A.S. A.C. was the PI of a Pharmasum Therapeutics small research grant to perform the behavioral experiments described in this study.

\section{References}

1. Down, J.L.H. Observations on an Ethnic Classification of Idiots. Lond. Hosp. Rep. 1866, 3, $259-262$.

2. Antonarakis, S.E.; Epstein, C.J. The challenge of Down syndrome. Trends Mol. Med. 2006, 12, 473-479. [CrossRef]

3. Lejeune, J.; Gautier, M.; Turpin, R. Study of somatic chromosomes from 9 mongoloid children. C. R. Hebd. Seances Acad. Sci. 1959, $248,1721-1722$.

4. Tejedor, F.; Zhu, X.R.; Kaltenbach, E.; Ackermann, A.; Baumann, A.; Canal, I.; Heisenberg, M.; Fischbach, K.F.; Pongs, O. minibrain: A new protein kinase family involved in postembryonic neurogenesis in Drosophila. Neuron 1995, 14, 287-301. [CrossRef]

5. Chen, H.; Antonarakis, S.E. Localisation of a human homologue of the Drosophila mnb and rat Dyrk genes to chromosome 21q22.2. Hum. Genet. 1997, 99, 262-265. [CrossRef]

6. Lyle, R.; Bena, F.; Gagos, S.; Gehrig, C.; Lopez, G.; Schinzel, A.; Lespinasse, J.; Bottani, A.; Dahoun, S.; Taine, L.; et al. Genotypephenotype correlations in Down syndrome identified by array CGH in 30 cases of partial trisomy and partial monosomy chromosome 21. Eur. J. Hum. Genet. 2009, 17, 454-466. [CrossRef]

7. Korenberg, J.R.; Chen, X.N.; Schipper, R.; Sun, Z.; Gonsky, R.; Gerwehr, S.; Carpenter, N.; Daumer, C.; Dignan, P.; Disteche, C. Down syndrome phenotypes: The consequences of chromosomal imbalance. Proc. Natl. Acad. Sci. USA 1994, 91, 4997-5001. [CrossRef]

8. Ahn, K.J.; Jeong, H.K.; Choi, H.S.; Ryoo, S.R.; Kim, Y.J.; Goo, J.S.; Choi, S.Y.; Han, J.S.; Ha, I.; Song, W.J. DYRK1A BAC transgenic mice show altered synaptic plasticity with learning and memory defects. Neurobiol. Dis. 2006, 22, 463-472. [CrossRef]

9. Dowjat, W.K.; Adayev, T.; Kuchna, I.; Nowicki, K.; Palminiello, S.; Hwang, Y.W.; Wegiel, J. Trisomy-driven overexpression of DYRK1A kinase in the brain of subjects with Down syndrome. Neurosci. Lett. 2007, 413, 77-81. [CrossRef]

10. Guimera, J.; Casas, C.; Estivill, X.; Pritchard, M. Human minibrain homologue (MNBH/DYRK1): Characterization, alternative splicing, differential tissue expression, and overexpression in Down syndrome. Genomics 1999, 57, 407-418. [CrossRef]

11. Moller, R.S.; Kubart, S.; Hoeltzenbein, M.; Heye, B.; Vogel, I.; Hansen, C.P.; Menzel, C.; Ullmann, R.; Tommerup, N.; Ropers, H.H.; et al. Truncation of the Down syndrome candidate gene DYRK1A in two unrelated patients with microcephaly. Am. J. Hum. Genet. 2008, 82, 1165-1170. [CrossRef]

12. Altafaj, X.; Dierssen, M.; Baamonde, C.; Marti, E.; Visa, J.; Guimera, J.; Oset, M.; Gonzalez, J.R.; Florez, J.; Fillat, C.; et al. Neurodevelopmental delay, motor abnormalities and cognitive deficits in transgenic mice overexpressing Dyrk1A (minibrain), a murine model of Down's syndrome. Hum. Mol. Genet. 2001, 10, 1915-1923. [CrossRef] [PubMed]

13. Liu, F.; Liang, Z.; Wegiel, J.; Hwang, Y.W.; Iqbal, K.; Grundke-Iqbal, I.; Ramakrishna, N.; Gong, C.X. Overexpression of Dyrk1A contributes to neurofibrillary degeneration in Down syndrome. FASEB J. 2008, 22, 3224-3233. [CrossRef] [PubMed]

14. Feki, A.; Hibaoui, Y. DYRK1A Protein, A Promising Therapeutic Target to Improve Cognitive Deficits in Down Syndrome. Brain Sci. 2018, 8, 187. [CrossRef] [PubMed]

15. Kim, O.H.; Cho, H.J.; Han, E.; Hong, T.I.; Ariyasiri, K.; Choi, J.H.; Hwang, K.S.; Jeong, Y.M.; Yang, S.Y.; Yu, K.; et al. Zebrafish knockout of Down syndrome gene, DYRK1A, shows social impairments relevant to autism. Mol. Autism 2017, 8, 50. [CrossRef]

16. Gupta, M.; Dhanasekaran, A.R.; Gardiner, K.J. Mouse models of Down syndrome: Gene content and consequences. Mamm. Genome 2016, 27, 538-555. [CrossRef]

17. Reeves, R.H.; Irving, N.G.; Moran, T.H.; Wohn, A.; Kitt, C.; Sisodia, S.S.; Schmidt, C.; Bronson, R.T.; Davisson, M.T. A mouse model for Down syndrome exhibits learning and behaviour deficits. Nat. Genet. 1995, 11, 177-184. [CrossRef]

18. Sago, H.; Carlson, E.J.; Smith, D.J.; Kilbridge, J.; Rubin, E.M.; Mobley, W.C.; Epstein, C.J.; Huang, T.T. Ts1Cje, a partial trisomy 16 mouse model for Down syndrome, exhibits learning and behavioral abnormalities. Proc. Natl. Acad. Sci. USA 1998, 95, 6256-6261. [CrossRef] 
19. Jarhad, D.B.; Mashelkar, K.K.; Kim, H.R.; Noh, M.; Jeong, L.S. Dual-Specificity Tyrosine Phosphorylation-Regulated Kinase 1A (DYRK1A) Inhibitors as Potential Therapeutics. J. Med. Chem. 2018, 61, 9791-9810. [CrossRef]

20. Nguyen, T.L.; Fruit, C.; Hérault, Y.; Meijer, L.; Besson, T. Dual-specificity tyrosine phosphorylation-regulated kinase 1A (DYRK1A) inhibitors: A survey of recent patent literature. Expert Opin. Ther. Pat. 2017, 27, 1183-1199. [CrossRef]

21. Gockler, N.; Jofre, G.; Papadopoulos, C.; Soppa, U.; Tejedor, F.J.; Becker, W. Harmine specifically inhibits protein kinase DYRK1A and interferes with neurite formation. FEBS J. 2009, 276, 6324-6337. [CrossRef] [PubMed]

22. Adayev, T.; Wegiel, J.; Hwang, Y.W. Harmine is an ATP-competitive inhibitor for dual-specificity tyrosine phosphorylationregulated kinase 1A (Dyrk1A). Arch. Biochem. Biophys. 2011, 507, 212-218. [CrossRef] [PubMed]

23. De la Torre, R.; De Sola, S.; Pons, M.; Duchon, A.; de Lagran, M.M.; Farre, M.; Fito, M.; Benejam, B.; Langohr, K.; Rodriguez, J.; et al. Epigallocatechin-3-gallate, a DYRK1A inhibitor, rescues cognitive deficits in Down syndrome mouse models and in humans. Mol. Nutr. Food Res. 2014, 58, 278-288. [CrossRef] [PubMed]

24. Guedj, F.; Sebrie, C.; Rivals, I.; Ledru, A.; Paly, E.; Bizot, J.C.; Smith, D.; Rubin, E.; Gillet, B.; Arbones, M.; et al. Green tea polyphenols rescue of brain defects induced by overexpression of DYRK1A. PLoS ONE 2009, 4, e4606. [CrossRef]

25. Ogawa, Y.; Nonaka, Y.; Goto, T.; Ohnishi, E.; Hiramatsu, T.; Kii, I.; Yoshida, M.; Ikura, T.; Onogi, H.; Shibuya, H.; et al. Development of a novel selective inhibitor of the Down syndrome-related kinase Dyrk1A. Nat. Commun. 2010, 1, 86. [CrossRef] [PubMed]

26. Rothweiler, U.; Eriksson, J.; Stensen, W.; Leeson, F.; Engh, R.A.; Svendsen, J.S. Luciferin and derivatives as a DYRK selective scaffold for the design of protein kinase inhibitors. Eur. J. Med. Chem. 2015, 94, 140-148. [CrossRef]

27. Rothweiler, U.; Stensen, W.; Brandsdal, B.O.; Isaksson, J.; Leeson, F.A.; Engh, R.A.; Svendsen, J.S. Probing the ATP-Binding Pocket of Protein Kinase DYRK1A with Benzothiazole Fragment Molecules. J. Med. Chem. 2016, 59, 9814-9824. [CrossRef] [PubMed]

28. Leblond, B.; Casagrande, A.-S.; Désiré, L.; Foucourt, A.; Besson, T. DYRK1 Inhibitors and Uses Thereof. WO Patent $2013 / 026806$ A1, 28 February 2013.

29. Foucourt, A.; Hedou, D.; Dubouilh-Benard, C.; Girard, A.; Taverne, T.; Casagrande, A.S.; Desire, L.; Leblond, B.; Besson, T. Design and synthesis of thiazolo[5, 4-f]quinazolines as DYRK1A inhibitors, part II. Molecules 2014, 19, 15411-15439. [CrossRef]

30. Coutadeur, S.; Benyamine, H.; Delalonde, L.; de Oliveira, C.; Leblond, B.; Foucourt, A.; Besson, T.; Casagrande, A.S.; Taverne, T.; Girard, A.; et al. A novel DYRK1A (dual specificity tyrosine phosphorylation-regulated kinase 1A) inhibitor for the treatment of Alzheimer's disease: Effect on Tau and amyloid pathologies in vitro. J. Neurochem. 2015, 133, 440-451. [CrossRef]

31. Sander, T.; Freyss, J.; von Korff, M.; Rufener, C. DataWarrior: An Open-Source Program For Chemistry Aware Data Visualization And Analysis. J. Chem. Inf. Modeling 2015, 55, 460-473. [CrossRef]

32. Lipinski, C.A.; Lombardo, F.; Dominy, B.W.; Feeney, P.J. Experimental and computational approaches to estimate solubility and permeability in drug discovery and development settings. Adv. Drug Deliv. Rev. 2001, 46, 3-26. [CrossRef]

33. Graczyk, P.P. Gini Coefficient: A New Way To Express Selectivity of Kinase Inhibitors against a Family of Kinases. J. Med. Chem. 2007, 50, 5773-5779. [CrossRef] [PubMed]

34. Kuhn, C.; Frank, D.; Will, R.; Jaschinski, C.; Frauen, R.; Katus, H.A.; Frey, N. DYRK1A is a novel negative regulator of cardiomyocyte hypertrophy. J. Biol. Chem. 2009, 284, 17320-17327. [CrossRef]

35. Arron, J.R.; Winslow, M.M.; Polleri, A.; Chang, C.P.; Wu, H.; Gao, X.; Neilson, J.R.; Chen, L.; Heit, J.J.; Kim, S.K.; et al. NFAT dysregulation by increased dosage of DSCR1 and DYRK1A on chromosome 21. Nature 2006, 441, 595-600. [CrossRef]

36. Olsen, L.; Rydberg, P.; Rod, T.H.; Ryde, U. Prediction of Activation Energies for Hydrogen Abstraction by Cytochrome P450. J. Med. Chem. 2006, 49, 6489-6499. [CrossRef] [PubMed]

37. de Bruyn Kops, C.; Stork, C.; Sicho, M.; Kochev, N.; Svozil, D.; Jeliazkova, N.; Kirchmair, J. GLORY: Generator of the Structures of Likely Cytochrome P450 Metabolites Based on Predicted Sites of Metabolism. Front. Chem. 2019, 7, 1-15. [CrossRef]

38. Stork, C.; Embruch, G.; Šícho, M.; de Bruyn Kops, C.; Chen, Y.; Svozil, D.; Kirchmair, J. NERDD: A web portal providing access to in silico tools for drug discovery. Bioinformatics 2019, 36, 1291-1292. [CrossRef]

39. Ackley, D.C.; Rockich, K.T.; Baker, T.R. Metabolic Stability Assessed by Liver Microsomes and Hepatocytes. In Optimization in Drug Discovery; Yan, Z., Caldwell, G.W., Eds.; Humana Press: Totowa, NJ, USA, 2004; pp. 151-162.

40. Costa, A.C.; Scott-McKean, J.J.; Stasko, M.R. Acute injections of the NMDA receptor antagonist memantine rescue performance deficits of the Ts65Dn mouse model of Down syndrome on a fear conditioning test. Neuropsychopharmacology 2008, 33, 1624-1632. [CrossRef]

41. Arbones, M.L.; Thomazeau, A.; Nakano-Kobayashi, A.; Hagiwara, M.; Delabar, J.M. DYRK1A and cognition: A lifelong relationship. Pharmacol. Ther. 2019, 194, 199-221. [CrossRef]

42. Wegiel, J.; Gong, C.X.; Hwang, Y.W. The role of DYRK1A in neurodegenerative diseases. FEBS J. 2011, 278, 236-245. [CrossRef]

43. Souchet, B.; Duchon, A.; Gu, Y.; Dairou, J.; Chevalier, C.; Daubigney, F.; Nalesso, V.; Creau, N.; Yu, Y.; Janel, N.; et al. Prenatal treatment with EGCG enriched green tea extract rescues GAD67 related developmental and cognitive defects in Down syndrome mouse models. Sci. Rep. 2019, 9, 3914. [CrossRef] [PubMed]

44. Pathak, A.; Rohilla, A.; Gupta, T.; Akhtar, M.J.; Haider, M.R.; Sharma, K.; Haider, K.; Yar, M.S. DYRK1A kinase inhibition with emphasis on neurodegeneration: A comprehensive evolution story-cum-perspective. Eur. J. Med. Chem. 2018, 158, 559-592. [CrossRef] 
45. Ruiz-Mejias, M.; Martinez de Lagran, M.; Mattia, M.; Castano-Prat, P.; Perez-Mendez, L.; Ciria-Suarez, L.; Gener, T.; Sancristobal, B.; Garcia-Ojalvo, J.; Gruart, A.; et al. Overexpression of Dyrk1A, a Down Syndrome Candidate, Decreases Excitability and Impairs Gamma Oscillations in the Prefrontal Cortex. J. Neurosci. 2016, 36, 3648-3659. [CrossRef] [PubMed]

46. Duchon, A.; Herault, Y. DYRK1A, a Dosage-Sensitive Gene Involved in Neurodevelopmental Disorders, Is a Target for Drug Development in Down Syndrome. Front. Behav. Neurosci. 2016, 10, e54285. [CrossRef]

47. Becker, W.; Soppa, U.; Tejedor, F.J. DYRK1A: A potential drug target for multiple Down syndrome neuropathologies. CNS Neurol. Disord. Drug Targets 2014, 13, 26-33. [CrossRef] [PubMed]

48. Laguna, A.; Barallobre, M.J.; Marchena, M.A.; Mateus, C.; Ramirez, E.; Martinez-Cue, C.; Delabar, J.M.; Castelo-Branco, M.; de la Villa, P.; Arbones, M.L. Triplication of DYRK1A causes retinal structural and functional alterations in Down syndrome. Hum. Mol. Genet. 2013, 22, 2775-2784. [CrossRef]

49. Courcet, J.B.; Faivre, L.; Malzac, P.; Masurel-Paulet, A.; Lopez, E.; Callier, P.; Lambert, L.; Lemesle, M.; Thevenon, J.; Gigot, N.; et al. The DYRK1A gene is a cause of syndromic intellectual disability with severe microcephaly and epilepsy. J. Med. Genet. 2012, 49, 731-736. [CrossRef]

50. Ryu, Y.S.; Park, S.Y.; Jung, M.S.; Yoon, S.H.; Kwen, M.Y.; Lee, S.Y.; Choi, S.H.; Radnaabazar, C.; Kim, M.K.; Kim, H.; et al. Dyrk1A-mediated phosphorylation of Presenilin 1: A functional link between Down syndrome and Alzheimer's disease. J. Neurochem. 2010, 115, 574-584. [CrossRef]

51. Ryoo, S.R.; Jeong, H.K.; Radnaabazar, C.; Yoo, J.J.; Cho, H.J.; Lee, H.W.; Kim, I.S.; Cheon, Y.H.; Ahn, Y.S.; Chung, S.H.; et al. DYRK1A-mediated hyperphosphorylation of Tau. A functional link between Down syndrome and Alzheimer disease. J. Biol. Chem. 2007, 282, 34850-34857. [CrossRef]

52. Kimura, R.; Kamino, K.; Yamamoto, M.; Nuripa, A.; Kida, T.; Kazui, H.; Hashimoto, R.; Tanaka, T.; Kudo, T.; Yamagata, H.; et al. The DYRK1A gene, encoded in chromosome 21 Down syndrome critical region, bridges between beta-amyloid production and tau phosphorylation in Alzheimer disease. Hum. Mol. Genet. 2007, 16, 15-23. [CrossRef]

53. Dierssen, M.; de Lagran, M.M. DYRK1A (dual-specificity tyrosine-phosphorylated and -regulated kinase 1A): A gene with dosage effect during development and neurogenesis. Sci. World J. 2006, 6, 1911-1922. [CrossRef] [PubMed]

54. Kentrup, H.; Joost, H.G.; Heimann, G.; Becker, W. Minibrain/DYRK1A gene: Candidate gene for mental retardation in Down's syndrome? Klin Padiatr 2000, 212, 60-63. [CrossRef] [PubMed]

55. Barallobre, M.J.; Perier, C.; Bove, J.; Laguna, A.; Delabar, J.M.; Vila, M.; Arbones, M.L. DYRK1A promotes dopaminergic neuron survival in the developing brain and in a mouse model of Parkinson's disease. Cell Death Dis. 2014, 5, e1289. [CrossRef] [PubMed]

56. Jones, E.L.; Aarsland, D.; Londos, E.; Ballard, C. A pilot study examining associations between DYRK1A and alpha-synuclein dementias. Neurodegener. Dis. 2012, 10, 229-231. [CrossRef]

57. Kim, E.J.; Sung, J.Y.; Lee, H.J.; Rhim, H.; Hasegawa, M.; Iwatsubo, T.; Min do, S.; Kim, J.; Paik, S.R.; Chung, K.C. Dyrk1A phosphorylates alpha-synuclein and enhances intracellular inclusion formation. J. Biol. Chem. 2006, 281, 33250-33257. [CrossRef] [PubMed]

58. Ferrer, I.; Barrachina, M.; Puig, B. Glycogen synthase kinase-3 is associated with neuronal and glial hyperphosphorylated tau deposits in Alzheimer's disease, Pick's disease, progressive supranuclear palsy and corticobasal degeneration. Acta Neuropathol. 2002, 104, 583-591. [CrossRef]

59. Ferrer, I.; Barrachina, M.; Puig, B.; Martínez de Lagrán, M.; Martí, E.; Avila, J.; Dierssen, M. Constitutive Dyrk1A is abnormally expressed in Alzheimer disease, Down syndrome, Pick disease, and related transgenic models. Neurobiol. Dis. 2005, 20, 392-400. [CrossRef]

60. Pozo, N.; Zahonero, C.; Fernandez, P.; Linares, J.M.; Ayuso, A.; Hagiwara, M.; Perez, A.; Ricoy, J.R.; Hernandez-Lain, A.; Sepulveda, J.M.; et al. Inhibition of DYRK1A destabilizes EGFR and reduces EGFR-dependent glioblastoma growth. J. Clin. Investig. 2013, 123, 2475-2487. [CrossRef]

61. Li, Y.L.; Ding, K.; Hu, X.; Wu, L.W.; Zhou, D.M.; Rao, M.J.; Lin, N.M.; Zhang, C. DYRK1A inhibition suppresses STAT3/EGFR/Met signalling and sensitizes EGFR wild-type NSCLC cells to AZD9291. J. Cell. Mol. Med. 2019, 23, 7427-7437. [CrossRef]

62. Fernandez-Martinez, P.; Zahonero, C.; Sanchez-Gomez, P. DYRK1A: The double-edged kinase as a protagonist in cell growth and tumorigenesis. Mol. Cell. Oncol. 2015, 2, e970048. [CrossRef]

63. Rachdi, L.; Kariyawasam, D.; Aiello, V.; Herault, Y.; Janel, N.; Delabar, J.M.; Polak, M.; Scharfmann, R. Dyrk1A induces pancreatic beta cell mass expansion and improves glucose tolerance. Cell Cycle 2014, 13, 2221-2229. [CrossRef] [PubMed]

64. de la Torre, R.; de Sola, S.; Hernandez, G.; Farré, M.; Pujol, J.; Rodriguez, J.; Espadaler, J.M.; Langohr, K.; Cuenca-Royo, A.; Principe, A.; et al. Safety and efficacy of cognitive training plus epigallocatechin-3-gallate in young adults with Down's syndrome (TESDAD): A double-blind, randomised, placebo-controlled, phase 2 trial. Lancet Neurol. 2016, 15, 801-810. [CrossRef]

65. Shen, W.; Taylor, B.; Jin, Q.; Nguyen-Tran, V.; Meeusen, S.; Zhang, Y.Q.; Kamireddy, A.; Swafford, A.; Powers, A.F.; Walker, J.; et al. Inhibition of DYRK1A and GSK3B induces human beta-cell proliferation. Nat. Commun. 2015, 6, 8372. [CrossRef] [PubMed]

66. Stringer, M.; Goodlett, C.R.; Roper, R.J. Targeting trisomic treatments: Optimizing Dyrk1a inhibition to improve Down syndrome deficits. Mol. Genet. Genomic. Med. 2017, 5, 451-465. [CrossRef] [PubMed]

67. Tahtouh, T.; Elkins, J.M.; Filippakopoulos, P.; Soundararajan, M.; Burgy, G.; Durieu, E.; Cochet, C.; Schmid, R.S.; Lo, D.C.; Delhommel, F.; et al. Selectivity, cocrystal structures, and neuroprotective properties of leucettines, a family of protein kinase inhibitors derived from the marine sponge alkaloid leucettamine B. J. Med. Chem. 2012, 55, 9312-9330. [CrossRef] [PubMed] 
68. Alvarez, M.; Estivill, X.; de la Luna, S. DYRK1A accumulates in splicing speckles through a novel targeting signal and induces speckle disassembly. J. Cell Sci. 2003, 116, 3099-3107. [CrossRef] [PubMed]

69. Liu, H.; Wang, K.; Chen, S.; Sun, Q.; Zhang, Y.; Chen, L.; Sun, X. NFATc1 phosphorylation by DYRK1A increases its protein stability. PLoS ONE 2017, 12, e0172985. [CrossRef]

70. Svendsen, J.S.; Stensen, W.; Porter, R.A. Benzothiazole Derivatives as DYRK1 Inhibitors. WO 2018/069468 A1, 23 February 2021

71. Alexeeva, M.; Aberg, E.; Engh, R.A.; Rothweiler, U. The structure of a dual-specificity tyrosine phosphorylation-regulated kinase 1A-PKC412 complex reveals disulfide-bridge formation with the anomalous catalytic loop HRD(HCD) cysteine. Acta Crystallogr. Sect. D Biol. Crystallogr. 2015, 71, 1207-1215. [CrossRef]

72. Krug, M.; Weiss, M.S.; Heinemann, U.; Mueller, U. XDSAPP: A graphical user interface for the convenient processing of diffraction data using XDS. J. Appl. Crystallogr. 2012, 45, 568-572. [CrossRef]

73. Kabsch, W. XDS. Acta Crystallogr. Sect. D Biol. Crystallogr. 2010, 66, 125-132. [CrossRef]

74. McCoy, A.J.; Grosse-Kunstleve, R.W.; Adams, P.D.; Winn, M.D.; Storoni, L.C.; Read, R.J. Phaser crystallographic software. J. Appl. Crystallogr. 2007, 40, 658-674. [CrossRef] [PubMed]

75. Adams, P.D.; Afonine, P.V.; Bunkóczi, G.; Chen, V.B.; Davis, I.W.; Echols, N.; Headd, J.J.; Hung, L.W.; Kapral, G.J.; Grosse-Kunstleve, R.W.; et al. PHENIX: A comprehensive Python-based system for macromolecular structure solution. Acta Crystallogr. Sect. D Biol. Crystallogr. 2010, 66, 213-221. [CrossRef]

76. Winn, M.D.; Ballard, C.C.; Cowtan, K.D.; Dodson, E.J.; Emsley, P.; Evans, P.R.; Keegan, R.M.; Krissinel, E.B.; Leslie, A.G.; McCoy, A.; et al. Overview of the CCP4 suite and current developments. Acta Crystallogr. Sect. D Biol. Crystallogr. 2011, 67, 235-242. [CrossRef]

77. Murshudov, G.N.; Skubák, P.; Lebedev, A.A.; Pannu, N.S.; Steiner, R.A.; Nicholls, R.A.; Winn, M.D.; Long, F.; Vagin, A.A. REFMAC5 for the refinement of macromolecular crystal structures. Acta Crystallogr. Sect. D Biol. Crystallogr. 2011, 67, 355-367. [CrossRef] [PubMed]

78. Schüttelkopf, A.W.; van Aalten, D.M. PRODRG: A tool for high-throughput crystallography of protein-ligand complexes. Acta Crystallogr. Sect. D Biol. Crystallogr. 2004, 60, 1355-1363. [CrossRef]

79. Hastie, C.J.; McLauchlan, H.J.; Cohen, P. Assay of protein kinases using radiolabeled ATP: A protocol. Nat. Protoc. 2006, 1, 968-971. [CrossRef] [PubMed]

80. Bain, J.; Plater, L.; Elliott, M.; Shapiro, N.; Hastie, C.J.; McLauchlan, H.; Klevernic, I.; Arthur, J.S.; Alessi, D.R.; Cohen, P. The selectivity of protein kinase inhibitors: A further update. Biochem. J. 2007, 408, 297-315. [CrossRef]

81. Czarna, A.; Wang, J.; Zelencova, D.; Liu, Y.; Deng, X.; Choi, H.G.; Zhang, T.; Zhou, W.; Chang, J.W.; Kildalsen, H.; et al. Novel Scaffolds for Dual Specificity Tyrosine-Phosphorylation-Regulated Kinase (DYRK1A) Inhibitors. J. Med. Chem. 2018, 61, 7560-7572. [CrossRef]

82. Victorino, D.B.; Bederman, I.R.; Costa, A.C.S. Pharmacokinetic Properties of Memantine after a Single Intraperitoneal Administration and Multiple Oral Doses in Euploid Mice and in the Ts65Dn Mouse Model of Down's Syndrome. Basic Clin. Pharmacol. Toxicol. 2017, 121, 382-389. [CrossRef] 